\title{
Developing Cc5 (Compassion, Celebration, Conviction, Creativity, and Community) Values through Bahasa Indonesia Lesson for Secretary
}

\author{
Maria Estri Wahyuningsih ${ }^{1}$, Rosalia Kurni Setyawati ${ }^{2}$, Gabriella Novianty Soedjarwo ${ }^{3}$, Jati \\ Wahyono Agustinus ${ }^{4}$, Petrus Dwi Ananto Pamungkas ${ }^{5}$ \\ \{estri.irnest01@gmail.com¹, kurni.tarakanita@gmail.com², novianty.gabriella@gmail.com³, \\ jati_wahyono@yahoo.co.id ${ }^{4}$,petrusananto@gmail.com ${ }^{5}$ \}
}

Secretary Department, Sekolah Tinggi Ilmu Komunikasi \& Sekretari Tarakanita, Kompleks Billy \& Moon, Pondok Kelapa, Jakarta 13450, Indonesia, info@ starki.id ${ }^{12345}$

\begin{abstract}
Elizabeth Gruyters in her book said that an education institution needs to equip each student with a good foundation of basic living values. Based on her idea, this study was conducted in order to elaborate the application of Cc5 values (Compassion, Celebration, Competence, Conviction, Creativity, and Community) in Bahasa Indonesia teaching learning process. This study wants to answer how teaching learning process can develop Cc5 values. The methodology implemented in this study is survey. The data was gathered by surveying 190 respondents using questionnaire. This study found out that the students tend to watch and learn the example of implementing Cc5 values during classroom activity. When they see how the lecturer gives examples and experience it directly how to implement those values, the students aut omatically follow that example in their college lives. Therefore, $\mathrm{Cc} 5$ values will inspirit the students to be a professional secretary in their work place.
\end{abstract}

Keywords: Compassion, Celebration, Competence, Conviction, Creativity, Community, teaching-learning activity.

\section{Introduction}

Talking about character building for students, it starts from the early beginning they enter formal education such as kindergarten until college. Character building in college is the continuation of character building from the previous educational level. Each college has its own uniqueness in term of formulating character building as stated in college's vision [1].

In giving character building in college, both lecturer and institution hold a responsibility in exposing the values to the students. It is expected that the character shaped in college can form student's character in society. In order to achieve that goal, sowing the moral values in community to each student is essential. Educational relation in character building process is relational-contextual which is formed in each educational institution. Each individual working in and related to education is the character builder for the students and others. Lecturer is the main agent since the students look up their lecturer more than other people in college. Thus, each lecturer must realize that he needs to behave accordingly with college's core values. 
Sekolah Tinggi Ilmu Komunikasi dan Sekretari Tarakanita, later in this paper is referred as STARKI, educates young women to be a professional secretary. In the office, a secretary is the henchwoman to herboss. She often handles many important things her boss assigns her to do. Thus, as secretary to-be, STARKI students learn how to think positively, easy to adapt, control herself well, and behave professionally. In order to facilitate the students to be such secretary, STARKI has Cc5 values. Cc5 stands for Compassion, Celebration, Competence, Conviction, Creativity, and Community.

This study was conducted to elaborate the classroomactivities which allow the students learn and internalize Cc5 values (Compassion, Celebration, Competence, Conviction, Creativity, and Community). The data for this study was taken in Bahasa Indonesia lesson conducted in STARKI. This study wants to scrutinize how Cc5 values were ins erted through Bahasa Indonesia teaching-learning activities.

\section{Review of Related Lite rature}

This part is divided into two parts. The first part is Education and Cc5 values (Compassion, Celebration, Competence, Conviction, Creativity, and Community). The second one is previous studies that conducted similar studies.

\subsection{Education and Cc5 Values}

Education is self-development process and the process to find their strength and potential in all as pects. Educational process should allow the students to build their purpose of life. After undergoing an educational process, the students are expected to have a wide view of life, their surroundings, and their place in society and nation. By having these attribute, the students will be a person with character and have a wide social knowledge [2].

Lecturer has many roles in educational process. Lecturer at least has three roles. The first role is facilitator. As a facilitator, the lecturer has a task to make the student find it easy to understand the learning material. The lecturer is a model as well; thus she needs to give example how to nurture a good living value to the students. The last role is as the motivator. The lecturer has to motivate the students to live their life to the fullest. She needs to show to the students that they need to get motivated to develop themselves and pursue their success. In order to achieve those noble roles, the lecturer needs to be a good designer as well. As a designer, a lecturer needs to design teaching-learning activities that boost students' character development. The lecturer is expected to insert the core living and moral value into her teaching [3].

The core values inserted in the teaching-learning activities can be derived from each college core values. As it was stated previously, STARKI has core values so-called Cc5. Preserving the institution's tradition on good behaviour, attitude, value, understanding, knowledge, and faith must be done by all academician in that institution. Cc5 serves as the guideline for preserving those good values that is passed form the predecess or to the next generation and it is the next generation's duty to preserve these good values.

Cc5 values are the Charles Borromeo Congregation's core values, which stands for Compassion, Celebration, Competence, Conviction, Creativity, and Community, serve as the 
spirit in running the educational programunder Charles Borromeo Congregation. Compassion is manifested in unconditional love and empathy. Celebration is the form of deep faith. Competence is the ability to res pect human dignity. Conviction is shown in the action to fight and being resilient in facing challenges. Creativity is the will to progress and develop. Community is a willingness to sacrifice and serve others sincerely. (1) The compassion values are manifested in caring and solidarity, sincere love, empathy and hospitality. Further, hospitality is shown through willingness to sacrifice, readiness, generous, caring, tolerant, open to dialogue, and serving. (2) The next value is celebration. This value is manifested in serving joyfully, embodying humility by realizing that we are tools in the hands of God, developing a faithful and hopeful attitude, and utilizing the talents for other's goodness. Celebration is als o manifes ted through valuing life as blessing, showing gratitude sincerely, carrying duty without mourn and demanding, readiness to help, and seeing the service as positive experience to be grateful of. (3) Competence is valued by creating space to develop and be independent, and developing talents optimally, serving responsibly, and developing exploration culture. Other things that can be done to reflect competence value are focus ing on professionalism, improving knowledge about nature, and utilizing provided media to develop oneself. Opening ourselves to the development of technology carefully, selectively, realistically as well as chasing the opportunity to serve and valuing honesty are the manifes tation of competence. (4) In short, showing conviction means being tough. This value is manifested in preserving tradition, being open consistently, adaptive positively toward surrounding, developing bravery in taking responsibility, proving and developing the service which is done faithfully and consistently. Other things can be done to carry this value are being responsible in obeying the normand system set by the institution, doing reflection and evaluation, facing challenges, creating happy, peaceful, and respectful atmosphere, and showing toughnes $s$ in the effort to get better. (5) Creativity is valued through contributing ideas creatively, having time and energy to serve optimally, being responsive and utilizing opportunities positively, creating something new, and daring to change. Other actions that reflect creativity are having many ideas and realizing those ideas in accordance with institution's regulations, finding and developing potential, practicing dialogical leadership, being active and having vision, being agile and wise, having willingness to ask and learn from others, and the last one is having enthusiasmand perseverance to keep learning. In short, the way we manifest the creativity value is by learn continuously and developing all talents creatively. (6) The last $c$ in c5 is community. Surani et.al (2008) wrote community value is manifes ted in mutual support, attention, res pect, completing each other, being open in building relationship, developing organizational skill, seeking true sisterhood, and creating homey atmosphere. To reflect this value, both students and lecturer, should create reconcile spirit, make peace with self, God, and nature, develop the discus sion and dialogue, service others happily, humbly, friendly, and openly, celebrate togetherness in togethernes s and bear failure in the spirit of love [4].

\subsection{Pre vious Studies}

There are some similar studies conducted prior to this study. There are at least three previous study related to introducing and internalizing school's values to the students through teaching-learning activities. The first one is the study conducted by Ris nawati. She explains thoroughly about the secretarial competencies. A competent secretary must be understanding, 
adaptive, open to critics, patient, polite, humble, responsible and helpful, and kind. Other characteristics of a professional secretary are can give proper compliment and can optimize her potential [5].

The next previous study was conducted by Khu sniati. She analyzed how to put character building in science class. She found that contextual approach can be used. Character building is put throughout the teaching-learning process fromplanning, main activities, and evaluation. By doing do, it is expected that Indonesian students can have better character as stated in Indonesia educational purpose [6].

The last previous study being referred to was conducted by Farida. She explained how to model the teaching-learning activity in college based on character building agenda. She mentioned the techniques, steps, and the implementation of character building in university. From her study, it was found out that characterbuilding should be inserted in the university curriculum, implemented in educational method and teaching -learning process. Moreover, character building should be the focus in obeying Tri Dharma Perguruan Tinggi (three pillars in university: teaching, researching, and community service) [7].

\section{Research Methodology}

The type of data used in this research is premier data. The data was gathered using questionnaire. There were 223 students of STARKI as the respondents. There were 22 students were tested in the validity and reliability tests. From the test, there were 201 respondents who were considered as valid and reliable. The secondary data was taken from book and internet.

The population in this study is all STARKI students semester III and V. There are 358 students who havetaken and passed Bahasa Indonesia clas s; 185 students from third semester and 173 students fromfifth semester. Before distributing the questionnaire, the questionnaire was tested its validity and reliability to 22 respondents. After that, the questionnaire was distributed to other respondents.

The s ample was taken using Proportionate Stratified Random Sampling. This technique was chosen since the data used in this study is heterogeneous and proportional. The amount of sample was counted based on Solvin formula: $n=N /\left(1+e^{2}\right)$. N is the population, e is the estimated error; this study set $5 \%$ error pos sibility. The result of this formula is 183 since the population of this study is 336 students. The sample taken in this study is 201 . This number was decided based on the formula semester 3 or semester 5 students $\mathrm{x} 201$. There were 98 respondents fromsemester 3 students and 103 respondents from semester 5 students were taken based on this formula.

The variable measured in this study is students' satisfaction of the teaching-learning result in Bahasa Indonesia class which implements $\mathrm{Cc} 5$ values. Each aspect was measured using Likert scale; the measured variable is jotted down into variable indicators. Those indicators served as the guideline in formulating questions or statements for questionnaire [8]. It has been mentioned earlier that there are 33 questions in this questionnaire. Those 33 questions were used to know how each cc5 values had been experienced by the student.

The gathered data was analysed using the following technique: (1) Counting the respondents who ans wered strongly agree, agree, neutral, disagree, strongly disagree. (2) Making Likert scale for all attributes and each attribute which consists of compassion, celebration, competence, conviction, creativity, and community. Likert scale was made based 
on the following formula: total ans wer $\mathrm{x}$ quality figure $\mathrm{x}$ amount of respondent. The quality figure for strongly agree is 5 , agree is 4 , neutral is 3 , disagree is 2 , and strongly dis agree is 1 . From this formula, the Likert scale for strongly agree answer is amount of answer $\mathrm{x} 5 \mathrm{x}$ amount of question. The Likert scale for agree answer is amount of answer $\mathrm{x} 4 \mathrm{x}$ amount of question. The Likert scale for neutral answer is amount of answer $\mathrm{x} 3 \mathrm{x}$ amount of question. The Likert scale for dis agree answer is amount of ans wer $\mathrm{x} 2 \mathrm{x}$ amount of question. The Likert scale for strongly disagree answer is amount of answer $\mathrm{x} 1 \mathrm{x}$ amount of question.

\section{Result and Discussion}

The questionnaire used in this res earch to gather the data. The questionnaire consisted of 33 ques tions to meas ure how the students see and experience the implementation of cc 5 value in STARKI. This sub part is going to provide the result of calculation for each value using Likert scale. Students' satisfaction was measured based on Likert Scale using this formula: (a) strongly agree $=201$ respondents $\times 5 \times 33$ questions $=33.165$; (b) agree $=201$ respondents $\times 4$ x 33 questions $=26.532$; (c) neutral $=201$ respondents $\times 3$ x 33 questions = 19.899; (d) disagree $=201$ respondents $\times 2 \times 33$ questions $=13.266$; and (e) strongly disagree $=201$ respondents $\times 1 \times 33$ questions $=6.633$.

Based on the calculation above, the Likert scale that can be made is as follow: (a) strongly agree $=26533-33165 ;$ (b) agree $=19900-26532 ;$ (c) neutral $=13267-19899$; (d) disagree $=6634-13266$; and (e) strongly dis agree $=0-6633$.

The total amount resulted from adding all respondents' answers for all attributes is 25.183. By comparing the result of respondents' answers and Likert scale so, the value 25.183 is included in agree classification. This has a meaning that the STARKI students agree that Cc5 values have been inserted and experienced in campus life.

\section{1 Compassion Attribute Data Analysis Result}

The result of students' respond gotten from adding all the respondents" answer for compas sion attribute is 3.086. By comparing the respondents' answers and Likert scale so, 3.086 value includes in agree clas sification. This shows that STARKI students agree that compas sion has been internalised in campus life, such as through loving sincerely and having empathy. Those two things can be seen when the lecturer serves the students sincerely and shows kindness to the students.

The students admitted that the lecturer has shown a good service when the lecturer opens to have dialogue about the material. By having the dialogue, the students can learn how to use good Bahasa Indonesia correctly and appropriately. The value of serving was also shown when the lecturerhelped the students in understanding the use of correct and appropriate Bahasa Indonesia. This service helps the students to be more enthusiastic during the les son. 


\section{2 Celebration Attribute Data Analysis Result}

The calculation result of students' opinion fromadding all the answers from celebration attribute is 3.681. By comparing res pondents"' result answer and Likert scale, the sco re 3.681 includes to agree category. This result implies that the STARKI s tudents agree that celebration value has been inserted in Bahasa Indonesia lesson and these values can be experienced in campus life such as through serving in happiness and readines s to serve. Lecturer gives the example of living in celebration value by serving the students well and always be ready to answer all the students' questions about Bahasa Indonesia. The students also have experienced celebration value themselves by using co rrect and appropriate Bahasa Indonesia in making sentence, arranging paragraph, and making summary. They learn Bahasa Indonesia in happy atmosphere.

Celebration value is als o related to willingness to show gratitude sincerely. The students agree that both lecturer and the students have implemented this value during classroom activity. The lecturer explained about spelling, sentence, paragraph, and summary patiently. On the same side, the students can use correct and proper Bahasa Indonesia to make sentence and arrange paragraph.

\section{3 Competence Attribute Data Analysis Result}

The total score of calculation from all answers for competence attribute is 4.575 . This score shows that the students agree that competence value has been implemented in Bahasa Indonesia les son and campus life. The competence value can be seen through creating chance to self-empowerment and independence. The students are expected to be responsible to use the correct s pelling, diction, sentence, paragraph, and format in making a s ummary. The students use the correct and proper Bahasa Indonesia res ponsibly; it can be proven on their summary.

The students can motivate thems elves to follow the clas s well. Self-motivation can be felt since they have taken Bahasa Indonesia since the early education. In college, Bahasa Indonesia is the subject that they have to take and still they have a high motivation in following the clas sroomactivities. They were still motivated to accept the material, practice to use good Bahasa Indonesia, and prove them that they can be more capable in making a sentence with correct spelling, diction, and make a good sentence and paragraph. Furthermore, the students learn continuously and do all the as signments well.

The students implement competence value by valuing honesty in using the correct spelling, sentence structure, and paragraph. In as signment and test time, the students can show honesty by preparing thems elves to face the test and avoiding any dishonest act such as cheating. The students answered all the questions based on their own capability.

Not only students, lecturer also shows her competence when she can teach and give information professionally. Competence value can be seen als o when the lecturer can prepare all administrative teaching things well such as formulating indicators, les son plan, and student assignment plan. Lecturer collaborates with her colleagues and supports each other such as in designing curriculum that can support the development on Cc5 values. The Bahasa Indonesia lecturers always try to insert $\mathrm{Cc} 5$ values in their teaching. The last thing to do is reflecting; they reflect whether the learning indicators had been achieved. 


\section{4 Conviction Attribute Data Analysis Result}

The students also agree that conviction value had been experienced during their college life. It is shown that the score of their answers is 4.710 and this score shows that the students agree on that. Conviction value was manifested through the willingness and being conscious to obey the rules. Both lecturer and students had dressed up in accordance with rules. Obeying the rule is one thing that becomes the focus still.

Conviction value can als o be seen when both lecturer and students can face the adversity. When they can pass all the adversities in understanding and using the correct and proper Bahasa Indonesia, they prove that they have conviction. Showing consistency in using Bahasa Indonesia appropriately is also the implementation of conviction value.

Another thing that can be done to implement conviction value is preserving local tradition and culture. Learning language is always clos ely related to preserving culture. By learning how the proper and good Bahasa Indonesia is and how to use it correctly, they have been contributed in preserving Indonesian culture.

\section{5 Creativity Attribute Data Analysis Result}

The next value being scored is creativity. Students were als o agree that creativity value can be seen since the score for this value is 5.395 which includes in agree category. From this score, we can also imply that the students were satisfied with the implementation of creativity value in college life. Creativity value was manifes ted when the lecturer allowed the students to develop their innovation in making sentence, paragraph, and summary.

During classroom activity, the way the lecturer made the students experience the creativity value is by supporting students' idea in introducing something new using various kinds of sentence type. By being able to vary their sentence type, the students proved that they have implemented the creativity value formulated in $\mathrm{Cc} 5$. The action they took such as adding some part in a sentence to forma new sentence type. They learnt how to vary the intonation to send a mess age and how to change positive sentence into negative one. They also practiced writing simple and compound sentences in class.

The lecturer supported the students to arrange the paragraph creatively. Giving them assignment on how to make a paragraph from a topic sentence was given on order to train themimproving their creativity. They could learn how to develop that topic sentence into a coherent and cohesive paragraph.

In making a summary, the lecturer facilitated the students to be familiar in many forms of summary. The lecturergave the as signment to make a summary in the form of abstract and otherkinds of summary. The purpose of doing so is to make the students could choose the kinds of summary based on their need.

The students also learn how to be creative in asking questions and learning from mistakes. The lecturer created chance to have dialogue with the students. The lecturer diligently gave feedback on students' work so that the students can learn from their mistakes. They have an experience to be given a direction when they seemed confused. When the lecturer gave thema feedback, they could keep their spirit to learn and this quality also shows that the students implemented creativity value. 


\section{6 Community Attribute Data Analysis Result}

The last attribute to be scored is community. The score gotten from this attribute is 3.736 which means the students also agree that the community value had been implemented in whole college life. STARKI livens up this value by willingness to share and building true friendship. By being open with other, students can feel the community value in this college.

In Bahasa Indonesia lesson, the students experienced community in joining in group discussion. The lecturer built group discussion with thestudents in making the students able to make a correct sentence, paragraph, and summary. Community value was also implemented by lecturer when she opened herself to critics and suggestion from the students. Lecturer also treated the students warmly.

By serving and explaining the material to the students well, the lecturer gave an example how to live in community value to the students. Giving an example is the effective way to make the students implement the value by themselves. This research found out that the students implemented the community value when they feel the warmatmos phere in clas sroom activities and in doing assignments.

\section{7 Developing Cc5 Values in Bahasa Indonesia Lesson}

As class facilitator and curriculum designer, a lecturerputs an effort to insert $\mathrm{Cc} 5$ values in her teaching. The lecturer is expected to design the activity in such a way to enhance the internalization of $\mathrm{Cc} 5$ values to the students. Bahasa Indonesia lecturer did the same thing. She brings the institution spirit to her Bahasa Indonesia students.

From the survey, it was found out that the students have experienced the $\mathrm{Cc} 5$ values in Bahasa Indonesia class. They, 190 respondents, agree that the lecturer has put and given example how to reflect the Cc5 value and allow the students to experience those values themselves. Based on their answer, here is the highest score to the smallest one: creativity, competence, conviction, celebration, community, and compassion.

\section{8 Cc5 values that can be developed in Bahasa Indonesia Lesson for Secretarial Study}

Compassion value guides thestudents and lecturer to love sincerely and have empathy. Compassion value was manifested in classroom activity through serving to "save" the students, developing humility toward the students, and serving in spirit.

Living in accordance with celebration values allows the students to su rrender ad have faith to God. This value was manifested through the following activities in Bahasa Indonesia les son serving in happiness, having willingness to help and being tough, and focusing on high readiness in serving the students.

During classroomactivity, Bahasa Indonesia lecturer has put competence value which focuses on improving expertise and mastering knowledge through creating the chance to develop students' self-empowerment and independence, serving responsibly, focusing on professionalis m, improving knowledge, and valuing honesty. 
Having bravery and toughness as the manifestation of conviction value was seen in Bahasa Indonesia less on through preserving tradition and local culture, developing the bravery to face consequences in service, having self-awareness to obey rules and regulation in the institution, having perseverance in facing difficulties, and facing adversity head on.

Creativity value puts a focus on finding new things and developing the willingness to improve. Creativity value was manifested in the following activity giving idea creatively for service improvement, seizing every opportunity and utilizing it positively, creating s omething new, willing to ask and learn fromothers, and having s pirit and perseverance to always learn.

Community value was inserted in Bahasa Indonesia les son by learning to share and build sis terhood. This valuecan be seen through being open in building relationship and cooperation with other parties and doing service with happiness, kindness, and opennes s spirit.

\section{Conclusion}

Cultivating the institution's spiritual values needs continuous commitment. Educational institution's spiritual values are the spirit that drives the educational service. Institution's spiritual values are the unique features that s hape the students' characteristics.

Cc5 is STARKI's core values. The growth of these values constitutes in each aspect of educational activity including in Bahasa Indonesia les son. By inserting Cc5 values, Bahasa Indonesia les son can contribute in shaping the students' characteristics to prepare thems elves entering the working world. They need to internalize Cc5 values since these values can help them to be a profes sional secretary. The result of character building through $\mathrm{Cc} 5$ will be much better if all class es can ins ert and implement these values in their teaching-learning activities.

\section{Acknowledgements}

The writers would like to thank the Department of Secretary, Tarakanita School of Communication \& Secretary (STARKI) for their support and opportunity given to us to attend the International Joint Conference on Science, Engineering and Technology (IJCSET). We als o would like to send our gratitude to IJCSET committee for giving us the opportunity to join the seminar and to contribute publis hing our research. We hope that our paper can enrich readers' knowledge. Ours incere gratitude goes to thereviewers who have given us valuable input to make our paper better and worth-published.

\section{References}

[1] D. Budimansyah, Y. Ruyadi, and N. Rusmana, Model Pendidikan Karakter di Perguruan Tinggi. Bandung: Universitas Pendidikan Indonesia, 2010.

[2] M. Sastrapratedja, Pendidikan Sebagai Humanisasi. Jakarta: Pusat Pendidikan Pancasila, 2013.

[3] D. K. A, Pendidikan Karakter Utuh dan Menyeluruh. Yogyakarta: Kanisius, 2012.

[4] S. CB et al., Pedoman Pelaksanaan Spiritualitas CB untuk Pelayanan Pendidikan. Yogyakarta: CB Media, 2008.

[5] V. N. Risnawati, "Kepribadian Sekretaris yang Kompeten,” J. STIE Semarang, vol. 3, no. 3, pp. 267-276, 2011.

[6] M. Khusniati, "Pendidikan Karakter Melalui Pembelajaran IPA,” JPII, vol. 1, no. 2, pp. 204-210, 2012.

[7] I. Farida, "Model Karakter di Perguruan Tinggi: Langkah Strategis dan Implementasinya di 
Universitas," J. Ilm. Adm. Publik dan Pembang., vol. 3, no. 1, pp. 445-451, 2012.

[8] Sugiyono, Metode Penelitian Kuantitatif, Kualitatif, dan Kombinasi (Mixed Methods). Bandung: Alfabeta, 2014. 